\title{
Regional Identity's Role in Cambodian Microfinance Adoption: Pushing, Pulling and Mooring Factors
}

\author{
Wei Sun ${ }^{1}$, Alisher Tohirovich Dedahanov ${ }^{2}$, Ho Young $\mathrm{Shin}^{2} \&$ Ki Su Kim² \\ ${ }^{1}$ School of Economic, Anyang Normal University, Anyang city, Henan Province, China \\ ${ }^{2}$ School of Business, Yeungnam University, Gyeongsan, Korea \\ Correspondence: Wei Sun, School of Economic, Anyang Normal University, Anyang city, Henan Province, \\ China. Tel: 86-176-0372-0269. E-mail: popupoler@tom.com
}

Received: September 22, 2019

doi:10.5539/ass.v15n12p29
Accepted: October 21, 2019

Online Published: November 13, 2019

URL: https://doi.org/10.5539/ass.v15n12p29

\begin{abstract}
By sampling usage intention factors of users in rural Cambodia, the study shows their effects on usage intention by integrating PPM and Reinforcement Sensitivity theories. Most of the behavioral factors are adopted from previous research. Perceived risk, reward sensitivity and knowledge prove to have significant effect on usage intention whereas regional identity does not. Regional identity proves to have moderating and negative effects on relationships between reward sensitivity, perceived risk, knowledge, and usage intention. The research results reinforce major roles for both government and microfinance institutions in considering and providing insights for future policy, management and investigations.
\end{abstract}

Keywords: regional identity, microfinance, push-pull-mooring theory, reinforcement sensitivity theory, Cambodia

\section{Introduction}

Cambodia is one of the least developed countries with largest economic development imbalance between urban and rural areas and there are some microfinance institutions, such as Wing, in rural areas to meet users' financial needs. In Cambodia, microfinance service has helped a lot in providing low-income rural households in a timely manner as well as improving household welfare through consumption smoothing, asset accumulation and women empowerment (Akotey \& Addjasi 2016). Although Microfinance services have increased access to finance among the poorest, increasing wealth of household and improving socio-economic level, there are also some puzzles about the adoption of microfinance. Firstly, most of the microfinance institutions are too small to afford a competitive salary mechanism or a powerful financial information system. Secondly, they have to try to reach customers by hand due to limited advertising budget since most Cambodian users are generally poor and low educated with limited experience in modern finance technics. Thus, it is necessary to focus on the financial, social, cultural, and economic environments of Cambodia to find factors that affect the adoption of microfinance.

Although some previous researches prove that microfinance's beneficial economic influence such as Akotey \& Addjasi (2016) and Warsame \& Ireri (2018), there are rare previous researches about users' adoption on microfinance, which leads to empirical evidence about its impact on Cambodian users to be inconclusive and controversial. Therefore, in this paper we examine the association of the targeting of Cambodian users with factors derived from PPM and RST theories as an underlying social characteristic in order to validate it empirically using a large sample of practitioners from microfinance services. Push-Pull-Mooring theory (PPM) theory is originated from demography, which is used to explain people's migration behavior (Chang et al., 2014). Pushing are negative effects that oblige individuals to leave an origin whereas pulling are positive effects that attract individuals toward a specific destination (Jung et al., 2017). Mooring was introduced to cover all personal, social, and cultural variables that moderate the migratory decision in order to explain the migration phenomenon more thoroughly (Bansal et al., 2005). Accordingly, in this research, the PPM model is applied to investigate individuals' behaviors and discussed about the factors of rural area user's adoption to microfinance.

Push effect, including perceived risk, represents factor that drive rural area users away from commercial banks in describing the low efficiency of procedure and high cost of loan. Pull effects, including reward sensitivity and knowledge, attract rural area users to use microfinance service as a complement to the large commercial banks. 
Mooring effect, including regional identity, may constrain rural area users' usage intention behavior. Thus, this research is designed to examine push, pull, and mooring's direct effects on usage intention empirically. This research also examines how the mooring variable moderately influence the relationship between push-pull factors and rural area users' usage intentions, which can help microfinance service managerial comprehend rural area users' usage intention behaviors and enable them to improve social interactions in attracting more users to lead to more profits and sales.

\section{Literature Review of PPM Theory}

Previous literatures that applied PPM into users' intention behavior are well-developed. Chang et al. (2014) apply PPM in their study to investigate user channel switching intention related to online stores and proves that push and pull effects have direct impacts on switching intention and mooring variable's moderating influence on the information search behavior. Wang \& Li (2016) proposes a PPM protecting intention influence model to explore factors that influence users adopting security measures behavior. In spite of all the related researches above, plenty of other studies have adopted PPM model into different research fields, such as Jung et al. (2017), Hsieh et al. (2012), Lin \& Huang (2014). It shows that PPM model's variables (push, pull and mooring) differ across research context and researchers should consider the distinct financial behavior characteristics to investigate how push, pull, and mooring factors will influence microfinance behavior in rural areas. Since this research is focused on advancing the understanding of rural users' usage intention in microfinance service, the framework considers the characteristics of microfinance service to identify the pull, push and mooring factors. Because pull and push factors are generally mutual correspondent (Wang \& Li 2016), push factors indicate large commercial banks' disadvantages, pull factors indicate microfinance services' advantages and mooring factor reflects moderating constraints between pull-push variables and microfinance service usage intention.

\section{Hypotheses Model}

\subsection{Perceived Risk and Usage Intention}

Perceived risk in this research is defined as an uncertainty combination plus seriousness of outcome involved. Since it is difficult to capture and measure its objective reality, perceived risk has been often defined as a relevant specific and situational parameter in different research fields (Yousafzai et al., 2003; Belanger \& Carter, 2008; Teo \& Liu, 2007; Crespo \& Rodríguez, 2008). It could be defined as the possibility that the use of an innovation might not be safe (Gerrard \& Cunningham, 2003). And it is also defined as economic, personal, functional, and privacy risk related to transaction specific uncertainty in the concept model of e-banking (Yousafzai et al., 2003). Furthermore, it depends on the purchase behavior, situation, and even cultural differences, which may vary depending on specific transactions and environments (Stone \& Gronhaug, 2007; Veloutsou \& Bian 2008). From the PPM model point of view, since a lot of studies indicate that push effects often include negative perceptions of the service provider, such as service failure, employee problems, and pricing issues that result in low satisfaction and low trust (Jung et al., 2017), this research tries to find pushing factor that can explain how microfinance services become an important complement to the large commercial banks instead of replacing them. Thus, in the context of microfinance service usage intention, we define it as the latent loss in seeking a return in using commercial bank service.

Push factor indicates that it drives rural customers' away from large commercial banks to find microfinance service as a complement. This research regarded perceived risk as the push-factor enforcing rural users unsatisfied with large commercial bank service. In practice of microfinance service adoption, perceived risk as the push factor focuses on time, finance and service. If rural areas have as many large commercial bank outlets or branches as cities do, large commercial banks will step into a difficult period with high cost and low profit. That is why there are only few branches of large commercial banks in rural areas. The rural customers prefer to handle business with microfinance services institutions nearby rather than large commercial banks, because running frequently between home and faraway bank branches will cause economic and financial losses with bad service experience. Furthermore, due to limited numbers of branches of large commercial bank, online or mobile banking systems in deal with financial business are only options for most of rural customers. No matter how easy to use those online banking systems of large commercial banks are, due to low education level, most of rural Cambodian users may feel confused in practice. Additionally, most large commercial bank are quite strict in the censorship of loan qualification, which makes the rural users spend a lot of time in shuttling back and forth between cities and villages before all the materials are prepared. By the way, the large commercial banks' deposit rate is relatively low compared with microfinance services, so there is a sense of perceived risk in using large commercial bank service for rural users. Quite a lot of researches have proved the relationship between user adoption and perceived risk (Tuu et al., 2011; Stone \& Gronhaug 2007). Hence, this study proposes the 
following hypothesis:

H1: Perceived risk in large commercial bank service positively affects the usage intention of microfinance service.

\subsection{Reinforcement Sensitivity Theory, Reward Sensitivity and Knowledge}

Reinforcement Sensitivity Theory (RST) is a prominent neuropsychological theory of personality, conceptualized in terms of emotion, motivation, and learning (Corr \& McNaughton, 2012), which is founded on the assumption that underpinning all major personality traits are basic systems of approach and avoidance (Corr et al., 2013). Reward sensitivity is a personality trait that reflects individual differences in the sensitivity and reactivity of the appetitive motivation system (Corr, 2004). It may contain approach motivation for ideas or activities that provide a sense of pleasure. Individuals with stronger reward sensitivity tend to show more positive affect and are more sensitive to, and more likely to approach, reward (Avila et al., 2008). It is also proved that individual differences in reward sensitivity are associated with better performance in fast tasks that require continuously changing rules (Avila et al., 2003). Because this research tries to find pulling factors that can explain how microfinance services attract consumers to adopt it, we introduce reward sensitivity as a individuals' intention that indicates rural users' reward expectation in the sensitivity and reactivity of usage intention.

Pull factors can increase rural users' intention to use microfinance service as a complement of large commercial banks. According to reinforcement sensitivity theory, risk-taking behaviors such as usage intention can be looked on as results from sensitivity to reward due to its sensitiveness to stimulation and reaction with personal motivation as well as the motivation to the special signals of punishment or rewarding. Reward sensitivity is a biologically-based predisposition to seek out rewarding substances and pursue situations and stimuli with high reward potential (Chang, 2017). Accordingly, reward sensitivity may enhance usage intention depending on different kinds of advantages that microfinance service can offer compared with large commercial banks. Rural Cambodian users with more reward sensitivity may intend to have more positive attitude and are more inclined to choose microfinance service as a financial aid. Thus, reward sensitivity can empower behavior intention to use microfinance to meet their task demands. Due to rural Cambodian stronger motivation towards reward seeking, such as quick access and low interest loans, high returns from deposit and financing products, those with high reward sensitivity and who prefer immediate reward, may find microfinance service is a nice option. Therefore:

$\mathrm{H} 2$ : Reward sensitivity positively affects usage intention.

Knowledge is not only an important role in purchasing decision making but also one of key factors in behavioral researches. It indicates information/perception associated with a product/service and its components, specifications, features, and techniques utilized to develop the product/service (Rindfleisch \& Moorman, 2001; Chang, 2017). As a role of pulling factor in PPM model, knowledge can be defined as perception or information that rural users have about microfinance service as a usage option and related techniques, attributes and underlying features. Specially, the interrelationship between pull factors is not under consideration due to the focus on the influence of pull factors on usage intention.

Quite a few researches have proved that users' knowledge about service or product influence significantly intentions and attitudes to adopt them (Burgess et al., 2013; Qian \& Yin, 2017; Wang et al., 2017; Liu et al., 2018). Salazar-Ordonez et al. (2018) indicates that knowledge can increase users' related attitude toward new product and will significantly and positively influence users' adoption. If rural Cambodian users get more knowledge about microfinance service, such as familiarity, skills and technics in using microfinance service (e.g., simple procedure, low loan interest, high deposit interest, local flavor) and receive advantage and benefits of microfinance service, they can hold more positive attitudes to adopt microfinance with more usage intentions.

\section{H3: Knowledge positively affects usage intention.}

\subsection{Mooring Effect (Regional Identity)}

Previous studies shows that the users prefer to acquire regional service/product because they believe local service/product to be more, traceable, reliable, wholesome etc. (Lorenz et al., 2015). Consumption of regional attitude is usually applied to describe users' regional, identity, citizenship and belonging (Lorenz et al., 2015; Verbeke \& Roosen, 2009). Regional identity is a useful factor in researches of purchase decisions and product assessments (Lorenz et al., 2015; Fraser et al., 2015). Lorenz et al. (2015) indicates that consumers want to deliver their regional belongings, identities or related citizenships in the process of consumption behavior. Users can hold regional identity to accept the fact that they should do something to improve reputation of regional services. The perception of regional cognition is useful in delivering themselves to others or external world. The 
formation of regional identity in adoption of local microfinance can be defined as the local users' belief on local microfinance institutions that can offer good service for them with a reasonable interest rate and localization service to meet their economic and educational development level. Trudel et al. (2016) prove that consumers handle service differently when it comes to regional perspectives, which can shape consumption behavior in different ways.

Mooring effect refers to factor that increases rural area users' intention to use microfinance service and moderates the relationships between them. Verbeke \& Roosen (2009) indicates that regional identify of the product moderates, positively, the interest of the consumer to purchase behavior. Lorenz et al. (2015) proves that the consumer wants to express his regional belonging, his identity and his citizenship. Sergio et al. (2019) have examined local consumers how to respond to and make sense of regional identity. Microfinance services are independent local corporations and are quite different from the branches of large commercial banks. Microfinance services often offer varieties of local-specific services because most shareholders and employees of microfinance services are locals and familiar with local business and cultures. Services with strong local features are always very popular among locals, which will strengthen low educated Cambodian locals' regional identity and encourage them to adopt the service of microfinance without hesitation. Particularly, the more regional identification locals possess, the less attracted Cambodian rural users are by the related financial knowledge. The more regional identification locals possess, the less local users will consider risk and reward. Thus, when the regional identity is higher, the push-pull factors' influence on the intention to accept the microfinance service could be lower. Therefore:

H4: Regional identity positively affects usage intention.

H5: Regional identity negatively moderates the relationship between perceived risk and usage intention.

H6: Regional identity negatively moderates the relationship between reward sensitivity and usage intention.

H7: Regional identity negatively moderates the relationship between knowledge and usage intention.

The proposed model is showed in Figure 1.

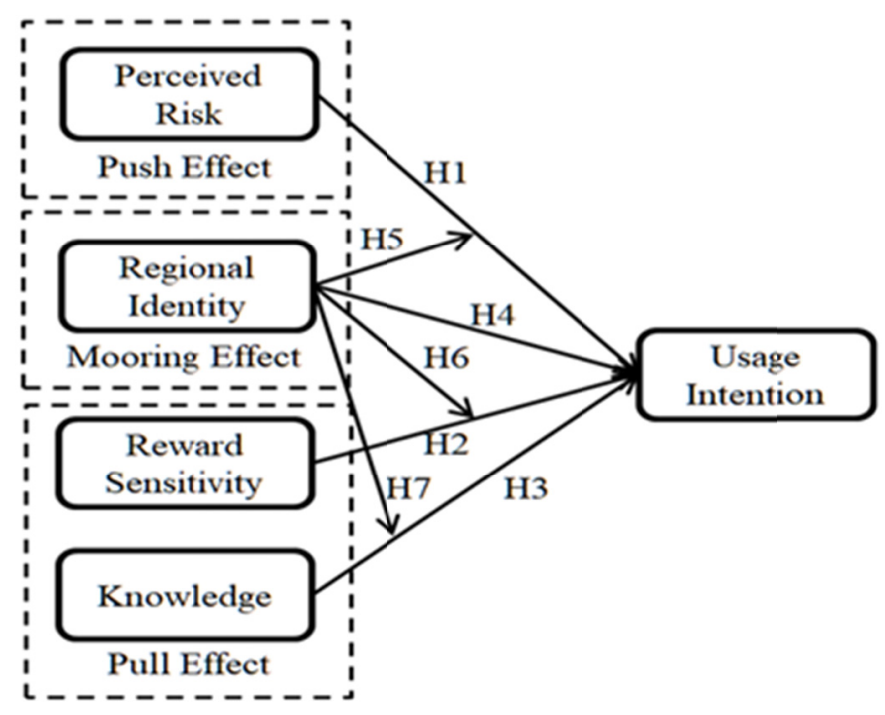

Figure 1. Proposed research model

\section{Measurement and Data Analysis}

It was necessary to survey users who are living in Cambodian rural areas and are familiar with microfinance services. With help of National Ministry of Agriculture of Cambodia, we collected data from 9 villages in the middle of Cambodia. These village were selected because they are typical Cambodian villages that dominated by agricultural economy. More than half of young people in villages went out to work in cities and sent money home every month by microfinance institutions such as Wing.

The Perceived Risk construct was measured using three items. ("It is inconvenient to use the services of commercial banks." "It is not wise to spend a lot of time to do business with commercial banks far away." "It costs too much to get loans from commercial banks."). They were rated on a seven-point Likert scale (1 Strongly disagree, 7 Strongly agree). 
The reward sensitivity construct was measured using three items. ("A good opportunity to get profits from microfinance services can motivate me to use it." "In most cases, I prefer to do something that pays off soon." "I want to be the best of people around me"). They were rated on a seven-point Likert scale (1 Strongly disagree, 7 Strongly agree).

The Knowledge construct was measured using three items. ("I am informed about what microfinance services can offer." "I am knowledgeable about microfinance service." "I am aware of microfinance service"). They were rated on a seven-point Likert scale (1 Strongly disagree, 7 Strongly agree).

The Regional Identity construct was measured using three items. ("I feel very concerned about the financial life of my region" "I would have a better opinion of myself by using local microfinance service instead of other banks." "I am very attached to my region."). They were rated on a seven-point Likert scale (1 Strongly disagree, 7 Strongly agree).

The Usage Intention construct was measured using three items. ("I am likely to use the local microfinance service." "I desire to use the local microfinance service." "I plan to use the local microfinance service."). They were rated on a seven-point Likert scale (1 Strongly disagree, 7 Strongly agree).

\subsection{Data Analysis}

Because this research model has never been tested before, PLS is an appropriate method to evaluate the reliability and validity of the measurement model, and analyze the structural model. The test of the structural model includes explained variance of endogenous constructs $\left(\mathrm{R}^{2}\right)$, path coefficients, and significance of path coefficients. We used bootstrap t-statistics with 5000 resamples.

\subsection{Descriptive Statistics}

Of these 253 participants, 156 were men (61.7\%) and 97 were women (38.3\%). The majority of respondents were aged between 20 and $30(62.3 \%)$. Table 1 shows the respondents of demographics.

Table 1. Demographic Statistics

\begin{tabular}{|c|c|c|c|}
\hline Category & Subject & $\mathrm{N}$ & $\%$ \\
\hline & Male & 156 & $61.7 \%$ \\
\hline Gender & Female & 97 & $38.3 \%$ \\
\hline \multirow{4}{*}{ Education Level } & Under High School & 192 & $75.9 \%$ \\
\hline & High School & 25 & $9.9 \%$ \\
\hline & Bachelor & 7 & $2.7 \%$ \\
\hline & Others & 29 & $11.5 \%$ \\
\hline \multirow{4}{*}{ Age } & $20-30$ & 157 & $62.3 \%$ \\
\hline & $30-40$ & 70 & $27.7 \%$ \\
\hline & $40-50$ & 19 & $7.5 \%$ \\
\hline & More than 50 & 7 & $2.5 \%$ \\
\hline \multirow{4}{*}{$\begin{array}{l}\text { Yearly } \\
\text { Income }\end{array}$} & $<1000 \$$ & 26 & $10.3 \%$ \\
\hline & $1000-2000 \$$ & 96 & $37.9 \%$ \\
\hline & $2000-3000 \$$ & 102 & $40.1 \%$ \\
\hline & $>3000 \$$ & 29 & $11.7 \%$ \\
\hline \multirow{4}{*}{$\begin{array}{c}\text { Use Frequency } \\
\text { per Month } \\
\text { in Recent Two Years }\end{array}$} & None & 34 & $13.6 \%$ \\
\hline & once & 97 & $38.3 \%$ \\
\hline & 2 or 3 times & 90 & $35.5 \%$ \\
\hline & $>3$ times & 32 & $12.6 \%$ \\
\hline \multirow{3}{*}{ Main Loan Amount } & $<500 \$$ & 77 & $30.5 \%$ \\
\hline & $500-1000 \$$ & 142 & $56.1 \%$ \\
\hline & $>1000 \$$ & 34 & $13.4 \%$ \\
\hline \multirow{4}{*}{ Loan Purpose } & Consumption & 102 & $40.4 \%$ \\
\hline & Small Business & 95 & $37.5 \%$ \\
\hline & Family Accident & 36 & $14.2 \%$ \\
\hline & Others & 20 & $7.9 \%$ \\
\hline
\end{tabular}




\subsection{Measurement Model}

As shown in Table 2, Cronbach's alpha for all measures exceed the recommended threshold value of 0.70 . Therefore, all measures are robust in terms of their reliability. The composite reliabilities range from 0.866 to 0.909, which are above the 0.70 cut-off. To assess convergent validity, AVE was calculated for each constructs in our proposed model (see Table 3). Since all construct's AVE are above the 0.50 cut-off, therefore, the results support convergent validity.

Table 2. Convergent Validity, Composite Reliabilities testing results

\begin{tabular}{|c|c|c|c|c|c|}
\hline Construct & Item & Standardized Loading & AVE & Composite Reliability & Cronbach's $\alpha$ \\
\hline \multirow{3}{*}{$\begin{array}{c}\text { Perceived } \\
\text { Risk }\end{array}$} & PR1 & 0.901 & \multirow{3}{*}{0.833} & \multirow{3}{*}{0.903} & \multirow{3}{*}{0.919} \\
\hline & PR2 & 0.887 & & & \\
\hline & PR3 & 0.865 & & & \\
\hline \multirow{3}{*}{$\begin{array}{c}\text { Reward } \\
\text { Sensitivity }\end{array}$} & RS1 & 0.810 & \multirow{3}{*}{0.752} & \multirow{3}{*}{0.866} & \multirow{3}{*}{0.905} \\
\hline & $\mathrm{RS} 2$ & 0.809 & & & \\
\hline & RS3 & 0.858 & & & \\
\hline \multirow{3}{*}{ Knowledge } & KN1 & 0.853 & \multirow{3}{*}{0.806} & \multirow{3}{*}{0.892} & \multirow{3}{*}{0.910} \\
\hline & KN2 & 0.902 & & & \\
\hline & KN3 & 0.875 & & & \\
\hline \multirow{3}{*}{$\begin{array}{l}\text { Regional } \\
\text { Identity }\end{array}$} & RI1 & 0.897 & \multirow{3}{*}{0.859} & \multirow{3}{*}{0.909} & \multirow{3}{*}{0.921} \\
\hline & RI2 & 0.804 & & & \\
\hline & RI3 & 0.876 & & & \\
\hline \multirow{3}{*}{$\begin{array}{c}\text { Usage } \\
\text { Intention }\end{array}$} & UI1 & 0.889 & \multirow{3}{*}{0.817} & \multirow{3}{*}{0.897} & \multirow{3}{*}{0.914} \\
\hline & UI2 & 0.921 & & & \\
\hline & UI3 & 0.831 & & & \\
\hline
\end{tabular}

Discriminant validity is considered in two steps. First, the Fornell and Larcker (1981) criterion is used to test whether the square root of a construct's AVE is higher than the correlations between it and any other construct within the model. As shown in Table 3, the diagonal is the square root of the AVE value. Each construct shares more variance with its own block of indicators than with another latent variable. Second, the factor loading of an item on its associated construct should be greater than the loading of another non-construct item on that construct. The results, presented in Table 4, indicate that all indicators loaded on their own construct more highly than on any other, supporting that the constructs are distinct.

Table 3. Descriptive statistics, Correlation matrix and square roots of AVE

\begin{tabular}{cccccccc}
\hline Construct & Mean & SD & PR & RS & KN & RI & UI \\
\hline PR & 4.155 & 1.197 & $\underline{0.901}$ & & & & \\
RS & 4.217 & 1.632 & 0.223 & $\underline{0.885}$ & & & \\
KN & 4.077 & 1.691 & 0.384 & 0.469 & $\underline{0.809}$ & $\underline{0.799}$ \\
RI & 3.908 & 1.522 & 0.327 & 0.379 & 0.401 & 0.522 & 0.481 \\
UI & 4.814 & 1.396 & 0.109 & 0.284 & $\underline{0.808}$ \\
\hline
\end{tabular}

Table 4. Loadings and cross-loadings

\begin{tabular}{lccccc}
\hline & PR & RS & KN & RI & UI \\
\hline PR1 & $\mathbf{0 . 7 0 1}$ & 0.456 & 0.503 & 0.189 & 0.554 \\
PR2 & $\mathbf{0 . 7 7 4}$ & 0.528 & 0.518 & 0.485 & 0.357 \\
PR3 & $\mathbf{0 . 7 9 1}$ & 0.409 & 0.599 & 0.448 & 0.304 \\
RS1 & 0.408 & $\mathbf{0 . 8 0 7}$ & 0.566 & 0.420 & 0.403 \\
RS2 & 0.208 & $\mathbf{0 . 8 5 1}$ & 0.428 & 0.327 & 0.609 \\
RS3 & 0.277 & $\mathbf{0 . 7 0 6}$ & 0.487 & 0.255 & 0.631 \\
KN1 & 0.401 & 0.621 & $\mathbf{0 . 7 1 3}$ & 0.362 & 0.445 \\
KN2 & 0.543 & 0.422 & $\mathbf{0 . 8 1 2}$ & 0.208 & 0.535 \\
KN3 & 0.362 & 0.548 & $\mathbf{0 . 8 3 9}$ & 0.284 & 0.234 \\
\hline
\end{tabular}




\begin{tabular}{llllll}
\hline RI1 & 0.486 & 0.508 & 0.297 & $\mathbf{0 . 7 7 6}$ & 0.244 \\
RI2 & 0.247 & 0.258 & 0.556 & $\mathbf{0 . 7 9 3}$ & 0.635 \\
RI3 & 0.601 & 0.452 & 0.507 & $\mathbf{0 . 8 8 1}$ & 0.367 \\
UI1 & 0.561 & 0.301 & 0.487 & 0.511 & $\mathbf{0 . 9 0 2}$ \\
UI2 & 0.494 & 0.402 & 0.328 & 0.406 & $\mathbf{0 . 8 8 6}$ \\
UI3 & 0.452 & 0.355 & 0.326 & 0.389 & $\mathbf{0 . 8 4 5}$ \\
\hline
\end{tabular}

In summary, all validation tests suggest that the items are both valid and reliable and could thus be used to evaluate the structural model.

\subsection{Structural Model}

Figure 2 depicts the results of PLS analysis, including the estimated path coefficients and the overall theoretical explanatory power of the model. As illustrated in Figure 2, Perceived Risk, Reward Sensitivity and Knowledge have a positive and significant effect on usage Intention, with path coefficients at $0.612(\mathrm{t}=2.471), 0.573$ $(\mathrm{t}=2.653)$ and $0.425(\mathrm{t}=3.440)$. Thus, H1, H2, H3 are supported except H4. Then, Regional Identity's negative moderating effect between Perceived Risk and Usage Intention is confirmed, with path coefficient at -0.674 $(\mathrm{t}=2.079)$, supporting H5. Meanwhile, Regional Identity's moderating effect between Reward Sensitivity and Usage Intention is confirmed, with path coefficient at $-0.886(\mathrm{t}=2.923)$, supporting H6. Regional Identity's moderating effect between Knowledge and Usage Intention is confirmed, with path coefficient at -0.373 $(\mathrm{t}=2.204)$, supporting H7. Overall, the four independent variables have explained a large proportion of the variance $(50.8 \%)$ in Usage Intention.

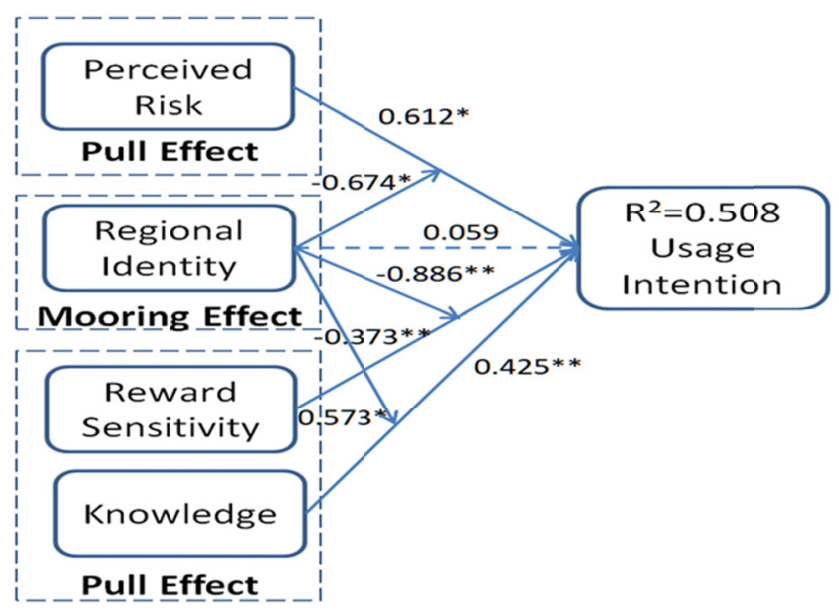

Figure 2. Structural model Note: standardized coefficients. ${ }^{* *} \mathrm{p}<0.01 ;{ }^{*} \mathrm{p}<0.05$

\section{Discussion}

These findings contribute in study on how rural Cambodian rural users' belief and perspectives towards microfinance service adoption. Taking into consideration the importance of RST and PPM theories in usage intention of microfinance service of Cambodia, this study focuses on how Cambodian rural users adopt the service of microfinance service. Specially, regional identity has no significant effect on usage intention could be due to Cambodian users' low education level, which make them to take it for granted that using microfinance is easy, safe and well rewarded and ignore influence of regional identify. Microcredit firms can retrieve the commercial or marketing potential of their advertisement, educating, service and pricing strategies to reduce the financial, advertising and competing costs related with the local service competition processes with commercial banks. Because the shareholders of microfinance firms not only pay lots of taxes to the local government but also generate a large number of employment opportunities in the area, local government is responsible for microfinance services to carry out supervision, management, branding and advertising to increase users' identification of microfinance services. Especially, the practical perceived risk caused by large commercial banks for both rural users should be eliminated by introducing the characteristics to local enterprises, institutions, communities and individuals to find their financial needs and teach them how to make best use of microfinance. Additionally, establishing good relationships between microfinance institutions and local users by offering low-interest loans, high-return investment products, flexible mortgage policy and quick loan censorship can enhance the reward sensitivity of users. Moreover, due to the low education level of most individual users, it is a 
good idea to carry out regular teaching programs, communication parties and advertising activities among users to make them acknowledge of the advantages of microfinance services.

This research had encountered some limitations which need to be taken into account. The consistency of the research result in different area context has to be verified in future studies. And future studies may consider microfinance service managers' characteristics and situational factors.

\section{References}

Avila, C., Barros-Loscertales, Ortet, G., Parcet, M., \& Ibanez, M. I. (2003). Set-shifting and sensitivity to reward: A possible dopamine mechanism for explaining disinhibitory disorders. Cognition \& Emotion, 17(6), 951-959. https://doi.org/10.1080/02699930341000031

Avila, C., Parcet, M. A., \& Barrós-Loscertales, A. (2008). A cognitive neuroscience approach to individual differences in sensitivity to reward. Neurotoxicity Research, 14(2-3), 191-203. https://doi.org/10.1007/BF03033810

Bansal, H. S., Taylor, S. F., \& James, Y. S. (2005). Migrating to new service providers: Toward a unifying framework of consumers' switching behaviors. J. Acad. Mark. Sci., 33(1), 96-115. https://doi.org/10.1177/0092070304267928

Belanger, F., \& Carter, L. (2008). Trust and risk in e-government adoption. Journal of Strategic Information System, 17, 165-176. https://doi.org/10.1016/j.jsis.2007.12.002

Burgess, M., King, N., Harris, M., \& Lewis, E. (2013). Electric vehicle drivers' reported interactions with the public: Driving stereotype change? Transp. Res. Part F: Traffic Psychol. Behav., 17, 33-44. https://doi.org/10.1016/j.trf.2012.09.003

Carvalhoa, S. W., Lunab, D., \& Goldsmith, E. (2019). The role of national identity in consumption: An integrative framework. Journal of Business Research, 56(1). https://doi.org/10.1016/j.jbusres.2019.01.056

Chang, I. C., Liu, C. C., \& Chen, K. (2014). The push, pull and mooring effects in virtual migration for social networking sites. Inf. Syst. J., 24(4), 323-346. https://doi.org/10.1111/isj.12030

Chang, J. (2017). The effects of buyer-supplier's collaboration on knowledge and product innovation. Ind. Mark. Manag., 65, 129-143. https://doi.org/10.1016/j.indmarman.2017.04.003

Corr, P. J. (2004). Reinforcement sensitivity theory and personality. Neuroscience and Biobehavioral Reviews, 28(3), 317-332. https://doi.org/10.1016/j.neubiorev.2012.09.013

Corr, P. J., \& Mc Naughton, N. (2012). Neuroscience and approach/avoidance personality traits: A two stage (valuation-motivation) approach. Neuroscience and Biobehavioral Reviews, 36, 2339-2354.

Corr, P. J., DeYoung, C. G., \& McNaughton, N. (2013). Motivation and personality: A neuropsychological perspective. Social and Personality Psychology Compass, 7, 158-175. https://doi.org/10.1111/spc3.12016

Crespo, A. H., \& Rodríguez, I. (2008). Explaining B2C e-commerce acceptance: An integrative model based on the framework by Gatignon and Robertson. Interacting with Computers, 20, 212-224. https://doi.org/10.1016/j.intcom.2007.11.005

Fraser, E., Legwegoh, A., Krishna, K. C., CoDyre, M., Dias, G., ... Hazen, S. (2015). Biotechnology or organic? Extensive or intensive? Global or local? A critical review of potential pathways to resolve the global food crisis. Trends in Food Science \& Technology, 48, 78-87. https://doi.org/10.1016/j.tifs.2015.11.006

Gerrard, P., \& Cunningham, J. B. (2003). The diffusion of Internet banking among Singapore consumers. International Journal of Bank Marketing, 21(1), 16-28. https://doi.org/10.1108/02652320310457776

Hersi, W. M., \& Mugambi, I. E. (2018). Moderation effect on mobile microfinance services in Kenya: An extended UTAUT model. Journal of Behavioral and Experimental Finance, 18, 67-75. https://doi.org/10.1016/j.jbef.2018.01.008

Hsieh, J. K., Hsieh, Y. C., Chiu, H. C., \& Feng, Y. C. (2012). Post-adoption switching behavior for online service substitutes: A perspective of the push-pull-mooring framework. Comput. Hum. Behav., 28(5), 1912-1920. https://doi.org/10.1016/j.chb.2012.05.010

Jung, J., Han, H., \& Oh, M. (2017). Travelers' switching behavior in the airline industry from the perspective of $\begin{array}{llll}\text { the } & \text { push-pull-mooring } & \text { framework. Tourism }\end{array}$ https://doi.org/10.1016/j.tourman.2016.07.018

Lin, T. C., \& Huang, S. L. (2014). Understanding the determinants of consumers' switching intentions in a 
standards war. Int. J. Electron. Commer., 19(1), 163-189. https://doi.org/10.2753/JEC1086-4415190105

Liu, Y., Hong, Z., Zhu, J., Yan, J., Qi, J., \& Liu, P. (2018). Promoting green residential buildings: Residents' environmental attitude, subjective knowledge, and social trust matter. Energy Policy, 112, 152-161. https://doi.org/10.1016/j.enpol.2017.10.020

Lorenz, B. A., Hartmann, M., \& Simons, J. (2015). Impacts from region-of-origin labeling on consumer product perception and purchasing intention - causal relationships in a TPB based model. Food Quality and Preference, 45, 149-157. https://doi.org/10.1016/j.foodqual.2015.06.002

Oscare, A. J., \& Adjasi Charles, K. D. (2016). Does Microcredit Increase Household Welfare in the Absence of Microinsurance? World Development, 77, 380-394. https://doi.org/10.1016/j.worlddev.2015.09.005

Qian, L., \& Yin, J. (2017). Linking Chinese cultural values and the adoption of electric vehicles: The mediating role of ethical evaluation. Transp. Res. Part D: Transp. Environ., 56, 175-188. https://doi.org/10.1016/j.trd.2017.07.029

Rindfleisch, A., \& Moorman, C. (2001). The acquisition and utilization of information in new product alliances: A strength-of-ties perspective. J. Mark., 65(2), 1-18. https://doi.org/10.1509/jmkg.65.2.1.18253

Salazar-Ordóñez, M., Rodríguez-Entrena, M., Cabrera, E. R., \& Henseler, J. (2018). Understanding product differentiation failures: The role of product knowledge and brand credence in olive oil markets. Food Qual. Prefer, 68, 146-155. https://doi.org/10.1016/j.foodqual.2018.02.010

Stone, R. N., \& Gronhaug, K. (2007). Perceived risk: Further considerations for the marketing discipline. European Journal of Marketing, 27(3), 39-50. https://doi.org/10.1108/03090569310026637

Teo, T. S. H., \& Liu, J. (2007). Consumer trust in e-commerce in the United States, Singapore and China. Omega, 35(1), 22-38. https://doi.org/10.1016/j.omega.2005.02.001

Trudel, R., Argo, J. J., \& Meng, M. D. (2016). The recycled self: Consumers' disposal decisions of identity-linked products. Journal of Consumer Research, 43(2), 246-264. https://doi.org/10.1093/jcr/ucw014

Tuu, H. H., Olsen, S. O., \& Linh, P. T. T. (2011). The moderator effects of perceived risk, objective knowledge and certainty in the satisfaction loyalty relationship. Journal of Consumer Marketing, 28(5), 363-375. https://doi.org/10.1108/07363761111150017

Veloutsou, C., \& Bian, X. M. (2008). A cross-national examination of consumer perceived risk in the context of non-deceptive counterfeit brands. Journal of Consumer Behavior, 7, 3-20. https://doi.org/10.1002/cb.231

Verbeke, W., \& Roosen, J. (2009). Market differentiation potential of country-of origin, quality, and traceability labeling. The Estey Centre Journal of International Law and Trade Policy, 10(1), 20-35.

Wang, S., Li, J., \& Zhao, D. (2017). The impact of policy measures on consumer intention to adopt electric vehicles: Evidence from China. Transp. Res. Part A: Policy Practice, 105, 14-26. https://doi.org/10.1016/j.tra.2017.08.013

Yousafzai, S., Pallister, J., \& Foxall, G. (2003). A proposed model of e-trust for electronic banking. Technovation, 23(11), 847-860. https://doi.org/10.1016/S0166-4972(03)00130-5

\section{Copyrights}

Copyright for this article is retained by the author(s), with first publication rights granted to the journal.

This is an open-access article distributed under the terms and conditions of the Creative Commons Attribution license (http://creativecommons.org/licenses/by/4.0/). 